\title{
Selecting improved Lotus nodulating rhizobia to expedite the development of new forage species
}

\author{
John Gregory Howieson • Ross Andrew Ballard • \\ Ron John Yates • Nigel Charman
}

Received: 23 March 2011 / Accepted: 13 July 2011 /Published online: 10 August 2011

(C) The Author(s) 2011. This article is published with open access at Springerlink.com

\begin{abstract}
Aims In the past decades the increasing focus by Australian pasture development programs on the genus Lotus has seen the evaluation of many species previously untested in Australia. In field trials, nodulation failure was commonplace. This work was undertaken to select effective symbionts for Lotus to ensure further agronomic evaluation of the genus was not compromised. The symbiotic needs of Lotus ornithopodioides were a particular focus of the studies.
\end{abstract}

Responsible Editor: Hans Lambers.

J. G. Howieson $(\bowtie) \cdot$ R. J. Yates

Centre for Rhizobium Studies, Crop and Plant Research Institute, Murdoch University,

Murdoch, WA 6150, Australia

e-mail: j.howieson@murdoch.edu.au

R. A. Ballard $\cdot$ N. Charman

South Australian Research and Development Institute,

Box 397, Adelaide, SA 5001, Australia

R. J. Yates

Department of Agriculture and Food,

Western Australia (DAFWA),

3 Baron Hay Crt,

South Perth, WA 6151, Australia

Present Address:

J. G. Howieson

School of Biological Sciences and Biotechnology,

Murdoch University,

Murdoch, WA 6150, Australia
Methods Glasshouse experiments were undertaken to evaluate symbiotic relationships between 15 Lotus spp and 23 strains of nodulating Mesorhizobium loti. This was followed by evaluation of elite rhizobial strains for their ability to persist and form nodules under field conditions.

Results Complex symbiotic interactions were recorded between strains of lotus rhizobia and the different species of Lotus. Notably, the rhizobia that are currently provided commercially in Australia for the inoculation of Lotus corniculatus (strain SU343) and Lotus uliginosus (strain CC829) did not form effective symbioses with the promising species $L$. ornithopodioides and $L$. maroccanus. No strain we evaluated was compatible with all the Lotus species, however several strains with a broad host range were identified. WSM1293 and WSM1348 were the most effective strains on $L$. ornithopodioides and $L$. peregrinus. These strains were also moderately effective on $L$. corniculatus (79 and $52 \%$ of SU343), less effective on L. maroccanus (26 and $49 \%$ of SRDI110) but were ineffective on $L$. uliginosus. The latter species overall had very specific rhizobial needs. Both WSM1293 and WSM1348 produced adequate levels of nodulation when inoculated on L. ornithopodioides, over two seasons at three field sites.

Conclusions Effective and persistent strains are now available that should allow the un-compromised evaluation of many of the contemporary Lotus species in the field. Selecting a strain for use in commercial inoculants will be more problematic, given the very 
large host-strain interactions for nitrogen fixation. Here, the balance of Lotus species which are adopted by farmers will have a strong bearing on which rhizobial strains are progressed to commerce.

Keywords Lotus spp. Mesorhizobium loti . Rhizobia $\cdot$ Nitrogen fixation · Pasture.

\section{Introduction}

Robson (1988) predicted that because of the great variation in management systems, and in edaphic and climatic environments within southern Australia, it was likely that the most appropriate legumes and procedures for maximising benefits from them would vary. Within 10 years of that prediction a second generation of annual pasture legumes had been selected and adopted for Mediterranean environments in Australian agriculture (Howieson et al. 1995, 2000a; Craig et al. 2000). These 'new' species of Ornithopus, Trifolium and Biserrula complemented the pre-existing sub-clover (Trifolium subterraneum L.) and medics (Medicago spp.) that had long been recognised as essential to maximising production in ley-farming systems (Cocks et al. 1980; Puckridge and French 1983).

A forage genus that remains to be fully exploited in Australian agriculture is Lotus, a diverse group of annual and perennial herbs consisting of more than 180 species (Allen and Allen 1981; Ayres et al. 2006). Only two species of Lotus (Lotus corniculatus L. and L. uliginosus Schukr. (syn L. pedunculatus)) are exploited commercially in Australia (Blumenthal et al. 1993), albeit their use is relatively minor (Harris et al. 1993; Hill and Donald 1998) and restricted to higher rainfall and waterlogging environments with rotational grazing practices (Ayres et al. 2006; Real et al. 2008). However, there are several other species of Mediterranean origin that may have the potential to benefit Australian farming systems (Kelman 1993). Most promising is perhaps $L$. ornithopodioides (L.), an annual, reseeding pasture legume with a number of desirable traits. These include a relatively deep root system, prolific seed production, tolerance to insects, excellent pod retention on the stems, and minimal pod shattering compared with other species in the genus (Loi et al. 2002), characters reflecting an optimal ideotype (Howieson et al. 2000a, b). A commercial release of this species is likely (A. Loi, pers. comm. Jan 2011). A second novel species, L. maroccanus (Ball.) is a short lived winter active perennial with salt and manganese tolerance (Schachtman and Kelman 1991) that has a putative role in water table control and has previously shown potential in pasture trials in Southern Australia (Hughes et al. 2008). Other Lotus species of current interest include L. creticus (L.), L. edulis (L.), L. peregrinus (L.) and L. tenuis Waldst. \& Kit. (syn. L. glaber) (Real et al. 2008; Teakle et al. 2010). There are also two species of Lotus that are indigenous and widespread in Australia, L. australis Andr. and L. cruentus Court (Jessop and Toelken 1986; Harden 1991), however they occur at low frequency, have little agronomic potential (Kelman 1993) and appear not to have left a legacy of rhizobial populations that are able to nodulate their Mediterranean counterparts. The unproductive Mediterranean species including L. subbiflorus (syn L. hispidus) and L. augustissimus are widely naturalised in southern Australia (Hussey et al. 2007) and the nodule bacteria for the latter species has been shown to fix nitrogen with both $L$. corniculatus and L. uliginosus (Brockwell et al. 1966). The potential for the nodule bacteria of the indigenous and naturalised Lotus spp. to compromise nitrogen fixation from commercial species directly, and to indirectly interact with the inoculants for Mediterranean Lotus spp. through lateral gene transfer should not be ignored (Sullivan et al. 1995; Nandasena et al. 2006).

Different species of Lotus commonly require specific strains of Mesorhizobium loti for effective nitrogen fixation (Brockwell et al. 1966; Gault et al. 1994). It is for this reason that two strains are provided commercially for the inoculation of Lotus in Australia. Strain SU343 is recommended for $L$. corniculatus, while strain CC829 is recommended for L. uliginosus (Bullard et al. 2005). While these two strains are effective on their respective hosts, they are reported to form ineffective symbioses with many of the other species of Lotus (Brockwell et al. 1966; Gault et al. 1994).

The experiments described here were principally undertaken to identify rhizobial strains that were compatible with L. ornithopodioides, following reports that nodulation failure of this legume was commonplace in field trials in both Western Australia and in South Australia (Loi et al. 2002). In particular, we were cognisant of the need to provide inoculant 
strains that would allow maximum nitrogen fixation from this and other promising Lotus species without compromising production of the commercial species L. corniculatus and L. uliginosus, other forages from the tribe Loteae including Dorycnium spp. (Davies et al. 2005) and Tetragonolobus spp., or even unrelated pasture species such as Biserrula pelecinus (L.) which are also nodulated by Mesorhizobium spp. (Nandasena et al. 2001). Saprophytic competence (Chatel and Parker 1973; Howieson 1995) of promising rhizobial strains was assessed in three soils, since this characteristic is known to be a critical factor in the regeneration and persistence of annual species such as L. ornithopodioides.

\section{Materials and methods}

Rhizobial and legume germplasm

Rhizobial strains were sourced from genetic resource centres at Murdoch University, Perth, Western Australia (strains with WSM prefix), SARDI, Adelaide, South Australia (strains with SRDI) and CC prefixes; the ' $\mathrm{CC}$ ' strains formerly curated by J. Brockwell of CSIRO, Canberra, Australian Capital Territory (Table 1).

Legume material (Table 2) was sourced primarily from the Australian legume genetic resource centres in Adelaide, South Australia (SARDI) and Perth, West Australia (Department of Agriculture and Food, WA).

Host range and effectiveness of the Lotus rhizobia

A series of glasshouse experiments were undertaken to examine the ability of rhizobial strains to nodulate and fix nitrogen with a diverse range of Lotus species.

In Experiments 1a and 1b, 22 strains of rhizobia (including four commercial mesorhizobial inoculants) were compared for their ability to nodulate and fix nitrogen with ten accessions of $L$. ornithopodioides. Experiments $2 \mathrm{a}, 2 \mathrm{~b}$ and $2 \mathrm{c}$ and Experiment 3 evaluated the more promising strains for nodulation and nitrogen fixation on a wider range of Lotus species.

General glasshouse procedures for Experiments $1 \mathrm{a}-\mathrm{b}$ and $2 \mathrm{a}-\mathrm{c}$ were as described in Howieson et al. (1995) and modified by Yates et al. (2005). Briefly, plants were grown for 6 weeks under axenic conditions in pots of steamed soil (equal parts of leached yellow sand and river sand) held in a temperature controlled glasshouse and supplied with adequate nutrients, minus N. Experimental design was a split plot factorial, with rhizobial strain as the main treatment and plant genotype as the sub-treatment.

In Experiment 3, the effectiveness of the two commercial Lotus strains (SU343 and CC829), and three elite strains identified in Experiments 1and 2 were compared in combination with five species of Lotus. Plants were grown in a mix of equal parts of course washed sand and vermiculite, contained in $130 \mathrm{~mm}$ diameter pots, which had been sterilised by autoclaving. A pot was planted with five pregerminated seedlings of a single Lotus species and then watered with $300 \mathrm{ml}$ of a nitrogen-free nutrient solution (McKnight 1949) in a laminar flow cabinet. After sowing and watering, the surface of the potting mix in each pot was covered with polypropylene beads. Subsequent water and nutrients were delivered via a sterile watering tube embedded below the surface to maintain the bacterial isolation of each pot. The pots were held on a wire grid to allow free drainage and a sterile paper filter was inserted at the bottom of the pot to minimise airborne contamination. The Lotus spp. were subjected to one of 14 treatments. The seedlings were either (i) inoculated 4 day after sowing with $10 \mathrm{ml}$ of a culture estimated to contain $>10^{6}$ cells $/ \mathrm{ml}$ of one of the 12 rhizobial strains (YMB Vincent 1970), (ii) not inoculated or (iii) not inoculated but supplied with $50 \mathrm{ml}$ of $15 \mathrm{mM}$ $\mathrm{NH}_{4} \mathrm{NO}_{3}$ pot $^{-1}$ added at $11,18,25,32,39,46$ and 53 day after sowing. Each of the treatment combinations was replicated four times and arranged in a randomised block design. Plants were grown in a shaded greenhouse $\left(25 / 20^{\circ} \mathrm{C}\right.$ mean day/night temperature), the shoots harvested 56 day after sowing and dried at $60^{\circ} \mathrm{C}$ for $72 \mathrm{~h}$. Shoot weight was determined and used as a measure of nitrogen fixation.

Field persistence of Lotus rhizobia

Experiments 4, 5 and 6 examined the field persistence of 13 promising rhizobial strains at Mannum (34 $54^{\circ} \mathrm{S}, 139^{\circ} 18^{\prime} \mathrm{E}$; sandy loam, $\left.\mathrm{pH}_{\mathrm{Ca}} 6.3\right)$, at Wynarka $\left(35^{\circ} 07^{\prime} \mathrm{S}, 139^{\circ} 43^{\prime} \mathrm{E}\right.$; sandy loam, $\left.\mathrm{pH}_{\mathrm{Ca}} 7.2\right)$ both in the Murray-Mallee region of South Australia, and two strains at Karridale $\left(34^{\circ} 08^{\prime} \mathrm{S}, 115^{\circ} 10^{\prime} \mathrm{E}\right.$; sandy loam, $\mathrm{pH}_{\mathrm{Ca}} 5.9$ ) in the south -west of Western Australia. A cross-row technique (Howieson and 
Table 1 Description of rhizobial strains used in the experiments
${ }^{a}$ nodule preserved and strain isolated in laboratory

${ }^{\mathrm{b}} \mathrm{GH}$ glasshouse in Australia

\begin{tabular}{|c|c|c|c|}
\hline Strain of rhizobia & Method of collection & Host of isolate & Country of origin \\
\hline WSM1284 & Nodule (in situ) ${ }^{\mathrm{a}}$ & Biserrula pelecinus & Greece \\
\hline WSM1497 & Nodule (in situ) & Biserrula pelecinus & Greece \\
\hline CC1192 & Nodule (in situ) & Cicer arietinum & Israel \\
\hline SU343 & Nodule (in situ) & L. corniculatus & USA \\
\hline WSM1294 & Nodule (in situ) & L. corniculatus & Morocco \\
\hline WSM1296 & Nodule (in situ) & L. corniculatus & Morocco \\
\hline WSM1297 & Nodule (in situ) & L. corniculatus & Italy \\
\hline WSM1307 & Nodule (in situ) & L. corniculatus & Morocco \\
\hline WSM1348 & Nodule (in situ) & Lotus sp. & Greece \\
\hline CC821 & Nodule (in situ) & L. maroccanus & Australia \\
\hline SRDI144 & Soil trapping $\left(\mathrm{GH}^{\mathrm{b}}\right)$ & L. maroccanus & Morocco \\
\hline SRDI110 & Soil trapping (GH) & L. ornithopodioides & Morocco \\
\hline SRDI137 & Soil trapping $(\mathrm{GH})$ & L. ornithopodioides & Morocco \\
\hline SRDI140 & Soil trapping $(\mathrm{GH})$ & L. ornithopodioides & Morocco \\
\hline SRDI210 & Soil trapping $(\mathrm{GH})$ & L. ornithopodioides & Greece \\
\hline SRDI225 & Soil trapping $(\mathrm{GH})$ & L. ornithopodioides & Greece \\
\hline WSM653 & Nodule (in situ) & L. ornithopodioides & Sardinia \\
\hline WSM1292 & Nodule (in situ) & L. ornithopodioides & Greece \\
\hline WSM2290 & Nodule (in situ) & L. ornithopodioides & South Africa \\
\hline WSM2316 & Nodule (in situ) & L. ornithopodioides & Greece \\
\hline WSM2317 & Nodule (in situ) & L. ornithopodioides & Greece \\
\hline WSM1646 & Nodule (in situ) & L. purshianus & USA \\
\hline WSM1648 & Nodule (in situ) & L. purshianus & USA \\
\hline CC829 & Nodule (in situ) & L. uliginosus & USA \\
\hline WSM805 & Nodule (in situ) & Lotus sp. & Greece \\
\hline WSM819 & Nodule (in situ) & Lotus sp. & Greece \\
\hline WSM1414 & Nodule (in situ) & L. uliginosus & Australia \\
\hline CC801a & Nodule (in situ) & Lotus edulis & Algeria \\
\hline WSM725 & Nodule (in situ) & Lotus sp. & unknown \\
\hline WSM1293 & Nodule (in situ) & Lotus sp. & Greece \\
\hline CC820 & Nodule (in situ) & Tetragonolobus palaestinus & Jordan \\
\hline
\end{tabular}

Ewing 1986) over a 2-year period was established to assess strain persistence and colonisation in experiments 4 and 5, whilst a small plot trial was established with a precision seeder for experiment 6 , sown in 2009 and monitored for nodulation into 2010.

Preparing inoculants for field experiments

The 13 strains of rhizobia used as the source of inoculant for the field experiments were cultured as previously described (Howieson et al. 1995) and allowed to mature in sterilised peat with the resultant cell density estimated on spread plates of yeast mannitol agar (YMA,Vincent
1970; Somasegaran and Hoben 1985). Each of the inoculants used contained $>1 \times 10^{9}$ colony forming units $\mathrm{g}^{-1}$ peat (the Australian industry standard), with the possible exception of strain WSM2316 for which a reliable population estimate was not obtained. Rhizobia were applied to the seed at 2-fold the rate recommended commercially (equivalent of $500 \mathrm{~g}$ peat inoculant applied to $25 \mathrm{~kg}$ of seed), and coated with Plastaid (Goliath Portland Cement Company) pelleting compound (experiments 4,5) or lime (experiment 6). An uninoculated control treatment was also sown for comparison. Each treatment was replicated four times and arranged in a randomised block design. 
Table 2 Description of Lotus germplasm used in the experiments a collection details not available

\begin{tabular}{|c|c|c|c|c|}
\hline Lotus spp. & Accession/cultivar & Origin of species & Growth & Expt. \\
\hline L. ornithopodioides L. & 97JH39 & Greece & Annual & $1 \mathrm{a}$ \\
\hline L. ornithopodioides L. & 98SNO-16 & Greece & Annual & $1 b$ \\
\hline L. ornithopodioides L. & 98LOI20 & Italy & Annual & $1 \mathrm{a}$ \\
\hline L. ornithopodioides L. & BR128 & Medit Basin, N Europe ${ }^{a}$ & Annual & $1 \mathrm{~b}$ \\
\hline L. ornithopodioides L. & BR298 & Medit Basin, N Europe ${ }^{a}$ & Annual & $1 b$ \\
\hline L. ornithopodioides L. & BR072 & Medit Basin, N Europe $^{a}$ & Annual & $1 \mathrm{a}$ \\
\hline L. ornithopodioides L. & PI308038 & Czech & Annual & $1 \mathrm{a}$ \\
\hline L. ornithopodioides L. & SA33845 & Tunisia & Annual & 5 \\
\hline L. ornithopodioides L. & SA33846 & Spain & Annual & $3,4,5$ \\
\hline L. ornithopodioides L. & SA5016 & Tunisia & Annual & 4 \\
\hline L. ornithopodioides L. & SA5017 & Tunisia & Annual & $1 \mathrm{a}$ \\
\hline L. ornithopodioides L. & SA5020 & Israel & Annual & $1 b$ \\
\hline L. ornithopodioides L. & SA834 & Tunisia & Annual & $1 b$ \\
\hline L. ornithopodioides L. & 2000ITA7.1.C & Italy & Annual & 6 \\
\hline L. arenarius Brot. & 54974 & Mediterranean basin ${ }^{a}$ & Perennial & $2 \mathrm{c}$ \\
\hline L. corniculatus $\mathrm{L}$. & cv. Grasslands Goldie & Spain & Perennial & $2 b, 3$ \\
\hline L. corniculatus L. & cv. San Gabriel & Mediterranean basin ${ }^{\mathrm{a}}$ & Perennial & 6 \\
\hline L. creticus L. & S1012 & Mediterranean basin ${ }^{\mathrm{a}}$ & Perennial & $2 \mathrm{c}$ \\
\hline L. cytisoides L. & not known & Mediterranean basin ${ }^{\mathrm{a}}$ & Perennial & $2 \mathrm{c}$ \\
\hline L. discolor E. Mayer & not known & East Africa & Perennial & $2 \mathrm{c}$ \\
\hline L. edulis L. & SA22716 & Mediterranean basin ${ }^{\mathrm{a}}$ & Perennial & $2 \mathrm{c}$ \\
\hline L. maroccanus Ball & SA12953 & Mediterranean basin ${ }^{\mathrm{a}}$ & Perennial & $2 \mathrm{c}, 3$ \\
\hline L. mearnsii (Britton) Greene & 27463 & Africa & Perennial & $2 \mathrm{c}$ \\
\hline L. peregrinus L. & SA13753 & Medit Basin, N Europe ${ }^{a}$ & Perennial & $2 \mathrm{c}$ \\
\hline L. peregrinus L. & SA5021 & Medit Basin, N Europe ${ }^{a}$ & Perennial & 3 \\
\hline L. purshianus (Benth.) & 610 & Medit Basin, N Europe ${ }^{a}$ & Annual & $2 \mathrm{c}$ \\
\hline L. subbiflorus Lagasca & Q18438 (P15304) & Medit Basin, N Europe ${ }^{a}$ & Perennial & $2 \mathrm{c}$ \\
\hline L. subbiflorus Lagasca & cv. Rincon & Medit Basin, N Europe ${ }^{\mathrm{a}}$ & Annual & $2 \mathrm{c}$ \\
\hline L. tenuis Waldst. \& Kit. & S2791 & $\mathrm{N}$ Africa, Europe, Asia ${ }^{\mathrm{a}}$ & Perennial & $2 \mathrm{c}$ \\
\hline L. uliginosus Schukr. & cv. Grasslands Maku & Medit Basin, N Europe $^{a}$ & Perennial & $2 \mathrm{a}, 3$ \\
\hline
\end{tabular}

In experiments 4 and 5 , in the year of establishment, $2.5 \mathrm{~m}$ rows containing seed coated with individual strains of rhizobia were established in the soil in 2000 and 2001, at Mannum and Wynarka respectively. The genotypes of seed were L. ornithopodioides accessions SA5016 and SA33846 respectively. Following senescence of the legume at the end of the growing season, the rhizobia were allowed to over-summer without disturbance. After opening rains the following season, uninoculated seeds of L. ornithopodioides (accession SA33845 at Mannum; SA33846 at Wynarka) were sown perpendicularly across the lines of inoculum (forming sub-plots) and the plants subsequently sampled 11 and 16 weeks after planting (at Mannum and Wynarka respectively) at four distances $(0-2,>2-12,>12-22$ and $>22$ to $32 \mathrm{~cm})$ from the initial line of inoculum. From each sampling region, 20 plants were selected at random and all nodules removed. Nodules were dried at $60^{\circ} \mathrm{C}$ for $48 \mathrm{~h}$ and then weighed.

In the small plot experiment (6), sown with a precision seeder, $L$. ornithopodioides and $L$. corniculatus (2000ITA7.1.C and San Gabriel respectively, $7 \mathrm{~kg} \mathrm{ha}^{-1}$ ) plots were sown $(1.2 \times 10 \mathrm{~m})$ into two banks each containing two replicates (four in total) arranged in a randomised block design but separated into species. Approximately $15 \mathrm{~h}$ before sowing seeds were inoculated separately with SU343 or the promising strain WSM1293 at the recommended inoculation rate $(250 \mathrm{~g}$ 
inoculant peat per $25 \mathrm{~kg}$ seed) and established in plots with uninoculated controls (sown first) in June 2009. A most probable number estimate (MPN, Brockwell et al. 1982) of background nodulating bacteria was undertaken prior to sowing. Plots were sub-sampled in October 2009 for shoot dry weight and nodulation assessment, and regenerating plants were again sampled in July 2010 for assessment of nodule occupancy using PCR fingerprint profiling (Yates et al. 2005).

Data interpretation and analysis

For experiments $1 \mathrm{a}-\mathrm{b}$ and $2 \mathrm{a}-\mathrm{c}$ symbioses were considered effective (E) where plant weight exceeded $75 \%$ of the $+\mathrm{N}$ treatment. Where plant weight was less than $20 \%$, the symbiosis was deemed ineffective (I), and in between these parameters the symbiosis was considered partially effective $(\mathrm{P})$.

For Experiment 3, the data were subjected to Analysis of Variance without transformation. Values for the $+\mathrm{N}$ treatment were excluded from the analysis and are not reported. For Experiments 4 and 5, the data were subjected to Analysis of Variance using a split plot model (sampling distances as the sub plots). The data were not transformed prior to analysis. Only four of the five replicates in Experiment 4 were analysed due to poor plant establishment in one field replicate. Standard errors were generated on data contained in Experiment 6 through Genstat $12^{\circledR}$ (Release 8.1, Lawes Agricultural Trust, Rothamsted Experimental Station)

\section{Results}

Rhizobial strain reaction with $L$. ornithopodioides (Experiments 1a-b)

The commercial Mesorhizobium inoculants for $L$. corniculatus (SU343), B. pelecinus (WSM1497), and Cicer arietinum (CC1192) failed to form nodules on any of the ten accessions of $L$. ornithopodioides (Table 3). The commercial inoculant for L. uliginosus (CC829) formed rudimentary nodules on four of the ten accessions only. Similarly, strains isolated from $L$. purshianus nodules (WSM1646 and WSM1648) collected from the USA were generally not infective on L. ornithopodioides. Contrastingly, there were ten strains, including WSM1284 that was originally isolated from $B$. pelecinus, that were both infective and able to fix nitrogen in symbiosis with $L$. ornithopodioides. Of these, strains WSM1293, WSM1348 and WSM805 resulted in most accessions of L. ornithopodioides having shoot dry weights greater than $75 \%$ of the nitrogen-fed control plants (Table 3).

Strain reaction on multiple Lotus spp. (Experiments 2a-c and Experiment 3)

No single strain was able to form an effective symbiosis with all the 15 Lotus species evaluated (Table 4). Strains WSM1293 and WSM1348 produced almost identical symbiotic profiles, forming effective associations with the same five Lotus species. Strain SU343 was only able to form effective symbioses with L. mearnsii, L. subbiflorus, and L. corniculatus. Strain CC829 also had a narrow host range and was unique in its ability to form effective symbioses with $L$. purshianus and L. uliginosus.

Similarly, with a wider set of strains in Experiment 3, CC829 was the only strain able to form an effective symbiosis (45 mg) with L. uliginosus cv. Maku (Table 5). Strains WSM1293 and WSM1348 produced the most effective symbioses with both $L$. ornithopodioides (91 and $89 \mathrm{mg}$ respectively) and L. peregrinus (69 and $58 \mathrm{mg}$ respectively), but were less effective than strain SU343 with L. corniculatus (48 mg). SRDI110, which was trapped from Moroccan soil with seed of L. ornithopodioides, was outstanding with $L$. maroccanus (110 mg) but relatively poor in association with its trap host. In fact, the strains trapped from Moroccan and Greek soils by L. ornithopodioides were generally less effective than strains isolated from nodules collected in situ from this host.

Field experiments (Experiments 4, 5 and 6)

All field sites were highly responsive to rhizobial inoculation. The MPN at Karridale prior to sowing returned an estimation of $<10$ cells $\mathrm{g}^{-1}$ soil capable of nodulating $L$. ornithopodioides despite the presence of naturalised L. subbiflorus, and $>10^{3}$ cells $\mathrm{g}^{-1}$ soil for $L$. corniculatus (data not shown). No nodules were detected in the uninoculated plots of L. ornithopodioides at Mannum whilst only low levels were detected in the uninoculated plots at Wynarka and Karridale (Tables 6 and 7). In contrast, 97\% of 
Table 3 Summary of the nodulation and symbiotic effectiveness ${ }^{\mathrm{a}}$ of 22 strains of rhizobia with ten accessions of Lotus ornithopodioides (Experiments 1a and 1b)

\begin{tabular}{|c|c|c|c|c|c|c|c|c|c|c|}
\hline Strain & BR072 & BR128 & BR298 & PI308038 & SA834 & SA5017 & SA5020 & 97JH39 & 98LOI20 & $985 \mathrm{~N} 0-16$ \\
\hline $\mathrm{CC} 829^{\mathrm{b}}$ & $\mathrm{X}$ & I & $\mathrm{X}$ & $\mathrm{X}$ & $\mathrm{X}$ & $\mathrm{X}$ & I & I & I & $\mathrm{X}$ \\
\hline $\mathrm{CC} 1192^{\mathrm{b}}$ & $\mathrm{X}$ & $\mathrm{X}$ & $\mathrm{X}$ & $\mathrm{X}$ & $\mathrm{X}$ & $\mathrm{X}$ & $X$ & $X$ & $\mathrm{X}$ & $\mathrm{X}$ \\
\hline SU343 ${ }^{\mathrm{b}}$ & $\mathrm{X}$ & $\mathrm{X}$ & $\mathrm{X}$ & $\mathrm{X}$ & $\mathrm{X}$ & $\mathrm{X}$ & $X$ & $X$ & $\mathrm{X}$ & $\mathrm{X}$ \\
\hline WSM1497 & $\mathrm{X}$ & $\mathrm{X}$ & $\mathrm{X}$ & $\mathrm{X}$ & $\mathrm{X}$ & $\mathrm{X}$ & $\mathrm{X}$ & $X$ & $\mathrm{X}$ & $\mathrm{X}$ \\
\hline WSM653 & E & $P$ & $\mathrm{P}$ & E & $P$ & E & E & E & $\mathrm{P}$ & E \\
\hline WSM725 & I & I & I & I & $\mathrm{P}$ & I & $\mathrm{P}$ & I & I & $\mathrm{P}$ \\
\hline WSM805 & E & E & $\mathrm{P}$ & E & E & E & E & E & $\mathrm{P}$ & E \\
\hline WSM819 & $\mathrm{P}$ & $\mathrm{P}$ & I & $\mathrm{P}$ & $\mathrm{E}$ & $\mathrm{P}$ & $\mathrm{P}$ & $\mathrm{P}$ & $\mathrm{P}$ & $\mathrm{E}$ \\
\hline WSM1292 & I & I & $\mathrm{P}$ & I & $\mathrm{P}$ & I & $\mathrm{P}$ & I & I & $\mathrm{P}$ \\
\hline WSM1293 & E & $\mathrm{E}$ & E & E & $\mathrm{E}$ & $\mathrm{E}$ & $\mathrm{E}$ & $\mathrm{E}$ & $\mathrm{P}$ & $\mathrm{E}$ \\
\hline WSM1294 & $\mathrm{P}$ & I & $\mathrm{P}$ & $\mathrm{P}$ & $\mathrm{E}$ & $\mathrm{P}$ & $\mathrm{E}$ & $\mathrm{P}$ & $\mathrm{P}$ & $\mathrm{P}$ \\
\hline WSM1296 & I & $\mathrm{P}$ & I & I & $P$ & I & $\mathrm{P}$ & I & I & $P$ \\
\hline WSM1297 & I & $\mathrm{P}$ & I & I & $\mathrm{P}$ & I & $\mathrm{P}$ & I & I & $P$ \\
\hline WSM1307 & $\mathrm{P}$ & $\mathrm{P}$ & $\mathrm{P}$ & $\mathrm{P}$ & $P$ & E & E & E & $\mathrm{P}$ & E \\
\hline WSM1348 & E & E & $\mathrm{P}$ & E & E & E & E & E & $\mathrm{P}$ & $\mathrm{P}$ \\
\hline WSM1414 & I & I & I & I & $\mathrm{P}$ & I & $\mathrm{P}$ & I & I & $\mathrm{P}$ \\
\hline WSM1646 & I & $\mathrm{P}$ & $\mathrm{P}$ & I & $\mathrm{P}$ & I & $\mathrm{P}$ & I & I & I \\
\hline WSM1648 & I & $\mathrm{P}$ & I & I & I & I & $\mathrm{P}$ & $\mathrm{P}$ & I & $P$ \\
\hline WSM2290 & I & $\mathrm{P}$ & $\mathrm{P}$ & I & I & I & $\mathrm{P}$ & $\mathrm{P}$ & I & $P$ \\
\hline WSM2316 & $\mathrm{P}$ & $\mathrm{P}$ & I & $\mathrm{P}$ & $P$ & $\mathrm{P}$ & E & E & I & E \\
\hline WSM2317 & $\mathrm{P}$ & E & $\mathrm{P}$ & $\mathrm{P}$ & E & $\mathrm{P}$ & $\mathrm{P}$ & E & $\mathrm{P}$ & E \\
\hline WSM1284 & E & I & $\mathrm{P}$ & E & E & E & E & E & $\mathrm{P}$ & E \\
\hline
\end{tabular}

${ }^{a}$ The capacity for $\mathrm{N}_{2}$-fixation (effectiveness) was determined by comparing yields of inoculated plants with $+\mathrm{N}$ controls and then separating the strains into four groups; effective $=>75 \%$ of $+\mathrm{N}$ control $(\mathrm{E})$, partially effective $=>20 \%$ but $<75 \%$ of $+\mathrm{N}$ control $(\mathrm{P})$, ineffective $=<20 \%$ of $+\mathrm{N}$ control (I) or no nodulation (X). ${ }^{\mathrm{b}}$ Current Australian commercial inoculant strains $(\mathrm{CC} 829=$ L. uliginosus (Group D), CC1192 = Cicer arietinum (Group D), SU343 = L. corniculatus, WSM1497 = Biserrula pelecinus. Note: L. ornithopodioides accessions 97JH39, BR072, PI308038, SA5017 and 98LOI20 tested in Experiment 1a. L. ornithopodioides accessions SA834, SA5020, BR128, 98SN0-16 and BR298 tested in Experiment 1b

uninoculated L. corniculatus plants achieved nodulation at Karridale.

In the cross-row trials, the mean weight of nodules per plant (across all sampling distances) formed on $L$. ornithopodioides varied significantly according to which strain of rhizobia had been established in the soil the previous year (Table 6). At Mannum, strain WSM1348 resulted in more nodule weight $(5.5 \mathrm{mg})$ than the other strains and five times more than the poorest strains (CC801a and WSM2316). At Wynarka, strain WSM1348 produced $6.6 \mathrm{mg}$ of nodules, just less than the four top ranked strains, which were statistically similar (SRDI210, WSM1293, WSM805 and SRDI225) producing between 7.9 and $9.8 \mathrm{mg}$ of nodules plant ${ }^{-1}$.
These four strains resulted in substantial nodulation, even in the outer sampling regions, with mean nodule weights of $6.9 \mathrm{mg}(0-2 \mathrm{~cm}), 9.9 \mathrm{mg}(>2-12 \mathrm{~cm}), 9.7$ $(>12-22 \mathrm{~cm})$ and $7.8 \mathrm{mg}(>22-32 \mathrm{~cm})$. By comparison, the poorest strains at this site (strains CC821, SRDI140 and SRDI137 both trapped from Moroccan soil) produced $<3 \mathrm{mg}$ of nodule dry weight in the $>22$ $32 \mathrm{~cm}$ sampling region.

At Karridale (experiment 6) background nodulation of L. corniculatus in the uninoculated plots, although substantial, was ineffective (Table 7). These nodules were small (4.3 mg plant ${ }^{1}$ ) and white and later identified by PCR RAPD to be associated with the naturalised L. subbiflorus (data not shown). The 
Table 4 Summary of the nodulation and symbiotic effectiveness $^{\mathrm{a}}$ of four strains of rhizobia (two Australian commercial strains and two highly effective strains on $L$. ornithopodioides) when inoculated onto 15 species of Lotus (Experiments 2a, $2 \mathrm{~b}$ and $2 \mathrm{c}$ )

${ }^{a}$ as previously defined, $\mathrm{N}=$ untested. ${ }^{\mathrm{b}}$ Current Australian commercial inoculant strains (CC829 $=$ L. uliginosus and SU343 = L. corniculatus)

\begin{tabular}{|c|c|c|c|c|c|}
\hline Lotus spp. & Accession/Cultivar & $\mathrm{CC} 829^{\mathrm{b}}$ & SU343 ${ }^{b}$ & WSM1293 & WSM1348 \\
\hline L. arenarius & 54974 & I & I & $\mathbf{E}$ & $\mathbf{E}$ \\
\hline L. creticus & S1012 & $\mathrm{I}$ & I & $\mathrm{P}$ & $\mathrm{P}$ \\
\hline L. cytisoides & & $\mathrm{N}$ & I & $\mathrm{P}$ & $\mathrm{N}$ \\
\hline L. maroccanus & SA12953 & $\mathrm{X}$ & $\mathrm{X}$ & $\mathbf{E}$ & $\mathbf{E}$ \\
\hline L. ornithopodioides & SA5020 & $\mathrm{I}$ & $\mathrm{X}$ & $\mathbf{E}$ & $\mathbf{E}$ \\
\hline L. peregrinus & SA13753 & I & I & $\mathrm{P}$ & $\mathrm{P}$ \\
\hline L. corniculatus & cv. Grasslands Goldie & I & $\mathbf{E}$ & $\mathrm{P}$ & $\mathrm{P}$ \\
\hline L. edulis & SA22716 & $\mathrm{X}$ & $\mathrm{P}$ & $\mathbf{E}$ & $\mathbf{E}$ \\
\hline L. mearnsii & 27463 & $\mathrm{I}$ & $\mathbf{E}$ & $\mathbf{E}$ & $\mathbf{E}$ \\
\hline L. discolor & & I & $\mathrm{X}$ & $\mathrm{X}$ & $\mathrm{X}$ \\
\hline L. subbiflorus & Q18438 (P15304) & I & $\mathbf{E}$ & I & I \\
\hline L. subbiflorus & cv. Rincon & $\mathrm{X}$ & $\mathrm{P}$ & I & I \\
\hline L. uliginosus & cv. Grasslands Maku & $\mathbf{E}$ & I & I & I \\
\hline L. purshianus & 610 & $\mathbf{E}$ & $\mathrm{P}$ & $\mathrm{X}$ & $\mathrm{X}$ \\
\hline L. tenuis & S2791 & $\mathrm{I}$ & $\mathrm{P}$ & I & I \\
\hline
\end{tabular}

nodule mass of $L$. corniculatus in plots inoculated with WSM1293 and SU343 was greater than for the uninoculated plots (12 mg, $13 \mathrm{mg} \mathrm{plant}^{-1}$ respectively) with $100 \%$ of plants nodulating (Table 7 ). The nodulation of $L$. corniculatus by WSM1293 produced a top dry weight equivalent to SU343 (Table 7).

The nodule mass produced upon $L$. ornithopodioides was greatest with WSM1293 (52 mg plant ${ }^{-1}$, cf $18 \mathrm{mg}$ plant $^{-1}$ SU343, Table 7), with commensurate differences in top dry weight of the plants $\left(0.7 \mathrm{~g} \mathrm{plant}^{-1} \mathrm{cf}\right.$.
0.4 g plant $^{-1}$ ). The uninoculated control achieved only sparse nodulation (less than $1 \mathrm{mg}$ nodule tissue plant $^{-1}$ ) and plants were pale and unthrifty.

The uninoculated plots of $L$. ornithopodioides, and also those treated with SU343, had increasing nodulation over time in the first year $(1 \%$ to $18 \%$, week 9 to 19; SU343 16\% to $79 \%$, Table 7) indicating progressive colonisation of these plots by nodulating rhizobia. Analysis of nodule occupancy by PCR in these plots in the second year (2010) showed them to

Table 5 Effect of inoculation treatment on the shoot dry weight (mg plant ${ }^{-1}$ ) of five species of Lotus (Experiment 3). Interaction LSD $(P=0.05)$ for comparing all values is 19

\begin{tabular}{|c|c|c|c|c|c|}
\hline $\begin{array}{l}\text { Inoculation } \\
\text { treatment }\end{array}$ & $\begin{array}{l}\text { L. uliginosus } \\
\text { cv. Maku }\end{array}$ & $\begin{array}{l}\text { L. corniculatus } \\
\text { cv. Goldie }\end{array}$ & $\begin{array}{l}\text { L. ornithopodioides } \\
\text { SA33846 }\end{array}$ & $\begin{array}{l}\text { L. peregrinus } \\
\text { SA5021 }\end{array}$ & $\begin{array}{l}\text { L. maroccanus } \\
\text { SA12953 }\end{array}$ \\
\hline Uninoc. & 5 & 7 & 11 & 6 & 3 \\
\hline CC821 & 6 & 15 & 12 & 25 & 36 \\
\hline CC829 & 45 & 10 & 8 & 6 & 5 \\
\hline SU343 & 9 & 48 & 9 & 6 & 3 \\
\hline SRDI110 & 3 & 23 & 45 & 8 & 101 \\
\hline SRDI137 & 3 & 26 & 55 & 10 & 61 \\
\hline SRDI140 & 6 & 26 & 35 & 32 & 5 \\
\hline SRDI144 & 5 & 24 & 33 & 6 & 66 \\
\hline SRDI210 & 5 & 25 & 65 & 5 & 31 \\
\hline SRDI225 & 3 & 8 & 48 & 51 & 7 \\
\hline WSM805 & 3 & 21 & 68 & 57 & 52 \\
\hline WSM1293 & 3 & 38 & 91 & 70 & 26 \\
\hline WSM1348 & 3 & 25 & 89 & 58 & 49 \\
\hline
\end{tabular}


Table 6 Effect of inoculation treatment on the weight of nodules on the roots of Lotus ornithopodioides sampled at four distances from lines of inoculant established the previous year in the field at Mannum (Experiment 4) and Wynarka
(Experiment 5) in South Australia. The LSD $(P=0.05)$ for comparing the effect of inoculation treatment on nodule weight (mean of all distances) is 1.7 for Mannum and 2.5 for Wynarka

\begin{tabular}{|c|c|c|c|c|c|c|c|c|c|c|}
\hline \multirow[t]{3}{*}{ Inoculation treatment } & \multicolumn{10}{|c|}{ Nodule dry weight (mg dry matter/plant) } \\
\hline & \multicolumn{2}{|l|}{$0-2 \mathrm{~cm}$} & \multicolumn{2}{|c|}{$>2-12 \mathrm{~cm}$} & \multicolumn{2}{|c|}{$>12-22 \mathrm{~cm}$} & \multicolumn{2}{|c|}{$>22-32 \mathrm{~cm}$} & \multicolumn{2}{|c|}{ All distances (mean) } \\
\hline & Mannum & Wynarka & Mannum & Wynarka & Mannum & Wynarka & Mannum & Wynarka & Mannum & Wynarka \\
\hline Uninoc. & 0.0 & 2.1 & 0.0 & 2.1 & 0.0 & 0.3 & 0.0 & 0.0 & 0.0 & 1.1 \\
\hline WSM1348 & 7.8 & 6.1 & 8.1 & 8.0 & 5.3 & 8.0 & 1.0 & 4.1 & 5.5 & 6.6 \\
\hline WSM1293 & 5.4 & 8.3 & 5.5 & 10.1 & 2.1 & 9.3 & 0.7 & 6.1 & 3.4 & 8.5 \\
\hline${ }^{\mathrm{a}} \mathrm{CC} 801 \mathrm{a}$ & 2.8 & - & 1.1 & - & 0.0 & - & 0.2 & - & 1.0 & - \\
\hline${ }^{\mathrm{a}} \mathrm{CC} 820$ & 4.8 & - & 4.4 & - & 2.8 & - & 0.3 & - & 3.1 & - \\
\hline WSM2316 & 1.5 & - & 1.2 & - & 0.0 & - & 0.1 & - & 0.7 & - \\
\hline WSM2317 & 5.0 & - & 4.9 & - & 2.5 & - & 0.3 & - & 3.2 & - \\
\hline CC821 & - & 5.1 & - & 8.1 & - & 1.9 & - & 2.9 & - & 4.5 \\
\hline SRDI137 & - & 4.5 & - & 7.5 & - & 3.3 & - & 2.0 & - & 4.3 \\
\hline SRDI140 & - & 3.9 & - & 6.0 & - & 5.7 & - & 2.3 & - & 4.5 \\
\hline SRD110 & - & 5.0 & - & 8.2 & - & 6.4 & - & 3.8 & - & 5.9 \\
\hline SRDI225 & - & 5.6 & - & 8.8 & - & 9.3 & - & 8.0 & - & 7.9 \\
\hline WSM805 & - & 6.2 & - & 8.5 & - & 8.3 & - & 9.3 & - & 8.1 \\
\hline SRDI210 & - & 7.5 & - & 12.0 & - & 12.0 & - & 7.7 & - & 9.8 \\
\hline
\end{tabular}

${ }^{\text {a }}$ Strains CC801a and CC820 were included at Mannum because they had previously been shown to form effective symbioses with $L$. ornithopodioides as well as L. halophilus and L. edulis. Strain CC820 is also known to form effective symbioses with Tetragonolobus purpureus and T. palaestinus (N. Charman and R.A. Ballard, unpublished data)

be dominantly nodulated by WSM1293 (100\%). SU343 was not detected in these plots. The uninoculated plots of L. corniculatus achieved $97 \%$ nodulation in 2009; as indicated by the MPN the background rhizobia were capable of nodulating this host. Analysis of these plots in 2010 showed them to be dominated by WSM1293 (67\%). None of the nodules formed on L. subbiflorus in and around the experiment in 2010 were identified as containing either SU343 or WSM1293.

\section{Discussion}

These studies highlight the diverse and often specific symbiotic interactions that occur between Lotus nodulating rhizobia and some of the many species that comprise the genus Lotus. This host-strain specificity at the species level has been previously described (Brockwell et al. 1966; Safronova et al. 2004), and despite beginning this research with a wider diversity of rhizobia than previous studies, we did not detect a strain that could be considered as having a sufficiently broad host range to fix nitrogen maximally with both the traditional commercial species of Lotus (L. corniculatus, L. uliginosus), and the emerging species. A similar scenario exists for Trifolium spp. (Howieson et al. 2005) but not the Medicago genus, where recent research has provided commercial manufacturers with broad host range strains (Howieson et al. 2000b; Ballard et al. 2004; Garau et al. 2005). The studies also emphasise that the rhizobia currently provided in Australia for the inoculation of L. corniculatus (strain SU343) and $L$. uliginosus (strain CC829), apart from having a narrow host range, are unable to satisfy the symbiotic needs of several promising species (principally $L$. ornithopodioides and $L$. maroccanus) being evaluated by contemporary Australian pasture development programs, and do not reliably colonise infertile soils. It is enigmatic that one of the most highly traded and valuable legume genera (Howieson et al. 2008) has not managed a stronger 
Table 7 Mean total nodule score plant ${ }^{-1}$, mean nodule rating plant $^{-1}$, percentage of plants nodulated, mean nodule dry weight plant ${ }^{-1}(\mathrm{mg})$, mean dry weight plant $^{-1}(\mathrm{~g})$ and total herbage production (mean D/W kg ha ${ }^{-1}$ ) at 9, 19 and 27 weeks

\begin{tabular}{|c|c|c|c|c|}
\hline \multirow[t]{2}{*}{ Measurement } & \multirow[t]{2}{*}{ Plant growth (wks) } & \multicolumn{3}{|c|}{ Plot inoculant treatment } \\
\hline & & Uninoculated & WSM1293 & SU343 \\
\hline \multicolumn{5}{|l|}{ Lotus ornithopodioides } \\
\hline Mean total nodules plant ${ }^{-1}$ & 9 & $0.25 \pm 0.2$ & $135 \pm 12.6$ & $7 \pm 3.8$ \\
\hline$\%$ plants nodulated & 9 & $1(n=80)$ & $100(\mathrm{n}=80)$ & $16(n=80)$ \\
\hline Mean nodule rating plant ${ }^{-1}$ & 19 & $0.21 \pm 0.1$ & $6.50 \pm 0.23$ & $2.13 \pm 0.08$ \\
\hline$\%$ plants nodulated & 19 & $18(n=119)$ & $100(n=102)$ & $79(n=94)$ \\
\hline $\mathrm{D} / \mathrm{W}$ plant $^{-1}$ & 19 & $0.258 \pm 0.038$ & $0.708 \pm 0.105$ & $0.410 \pm 0.066$ \\
\hline Nodule mass plant ${ }^{-1}(\mathrm{mg})$ & 19 & $1.073 \pm 0.6$ & $52.597 \pm 2.3$ & $17.302 \pm 2.3$ \\
\hline Mean D/W kg ha ${ }^{-1}$ & 27 & $890 \pm 45$ & $6450 \pm 75$ & $3590 \pm 55$ \\
\hline \multicolumn{5}{|l|}{ Lotus corniculatus } \\
\hline Mean nodule rating plant ${ }^{-1}$ & 19 & $2.67 \pm 0.3$ & $3.69 \pm 0.5$ & $4.24 \pm 0.5$ \\
\hline$\%$ plants nodulated & 19 & $97(\mathrm{n}=81)$ & $100(\mathrm{n}=65)$ & $100(\mathrm{n}=68)$ \\
\hline $\mathrm{D} / \mathrm{W}$ plant $^{-1}$ & 19 & $0.0356 \pm 0.001$ & $0.102 \pm 0.017$ & $0.128 \pm 0.016$ \\
\hline Nodule mass plant ${ }^{-1}(\mathrm{mg})$ & 19 & $4.355 \pm 0.3$ & $12.05 \pm 1.7$ & $13.0825 \pm 1.7$ \\
\hline Mean D/W kg ha ${ }^{-1}$ & 27 & $690 \pm 30$ & $1590 \pm 40$ & $3450 \pm 20$ \\
\hline
\end{tabular}

after sowing generated by Lotus ornithopodioides (2000ITA7.1. C) and L. corniculatus (cv. San Gabriel) at Boathaugh farm, Augusta, WA 2009 (Experiment 6) foothold in Australia, an observation perhaps explained by these results.

Nonetheless, these studies have identified a suite of effective strains which can now be used for the inoculation of some hitherto unexploited Lotus species. Pasture evaluators have been provided with the outstanding strains WSM1293 and WSM1348 for $L$. ornithopodioides and strain SRDI110 for L. maroccanus over the last decade, thus removing symbiotic impediments to the evaluation of these species.

This study has also exposed the high level of strain specificity in the weedy naturalised species $L$. subbiflorus and the promising salt tolerant species $L$. tenuis which, like L. uliginosus, achieved nitrogen fixation only with one experimental strain. However, some cross nodulation was achieved. L. purshianus formed an effective symbiosis with CC829 and SU343, and L. corniculatus, L. edulis and L. mearnsii achieved effective and partially effective symbioses with SU343, WSM1293 and WSM1348.

For the strains that were effective at nitrogen fixation with $L$. ornithopodioides, their performance could be further separated on their ability to reliably produce nodules under field conditions. The ability to colonise the soil, and to persist through seasons subsequent to the year of inoculation is a fundamental requirement for inoculant quality strains developed for self-regenerating annual legumes (Chatel and Parker 1973; Howieson 1995). At Mannum, strain WSM1348 produced five times the nodule mass of strain CC801a, while at Wynarka there was a two-fold difference in nodule mass, the best strains being SRDI210 and WSM1293. Background nodule bacteria associated with indigenous L. subbiflorus at Karridale, whilst incapable of nodulation of $L$. ornithopodioides, were able to nodulate $L$. corniculatus. However despite this, nodules of $L$. corniculatus were dominantly occupied by WSM1293 by the second year of the experiment in uninoculated plots. This indicates either a high level of competitiveness by WSM1293 in this niche against the background $L$. subbiflorus nodulating bacteria, or selection for effective nodulation as described Yates et al. (2005, 2008). Generally speaking, the persistence of the best strains was outstanding, with significant levels of nodulation occurring even in the 22-32 cm sampling region in South Australia. Where strains persist poorly, such as is the case with Sinorhizobium meliloti in very acid soils, nodules are rarely found past the $12 \mathrm{~cm}$ sampling region (Howieson and Ewing 1986; Ballard et al. 2004). While the 
persistence of the Lotus rhizobia in the sandy neutral soils $\left(\mathrm{pH}_{\mathrm{Ca}} 6.3\right.$ and 7.2) is encouraging, their evaluation in the more acidic soil was important as Lotus spp. are often promoted as having moderate tolerance of acidity (Schachtman and Kelman 1991), albeit in experiments conducted asymbiotically. There have been infrequent reports of nodulation problems in acidic environments, as well as large plant growth responses to lime application in Lotus (Wedderburn 1986; Lowther et al. 1987; Patrick and Lowther 1992) so it cannot be assumed that all genetic material related to this symbiosis is acid tolerant.

Effective strains are now available for several of the exotic Lotus species being evaluated in Australian pasture programs. Although many other factors could be considered in selecting the strains that will be used in commercial inoculants (see Brockwell et al. 1995), several of the strains in this study look to be promising candidates based on their effectiveness and soil persistence. An important character not yet assessed, however, is genetic stability. The Mesorhizobium have emerged as a genus with a propensity for transmission of a symbiosis island to resident soil bacteria (Sullivan et al. 1995; Nandasena et al. 2006), facilitated by a set of excision and integration genes (Nandasena et al. 2009). For promising strains such as WSM1293 we should exploit the genome sequence information now available to identify whether a similar set of transmission enabling genes are present. WSM1284, originally isolated from $B$. pelecinus and previously shown to have a broad host range (Nandasena et al. 2001), nodulated and fixed nitrogen well with $L$. ornithopodioides, suggesting it may well have been the recipient (and potentially a donor) of symbiotic genes. If the majority of background nodulating bacteria for L. subbiflorus in Australian soils are Bradyrhizobium, as reported for this legume in Uruguay (Irisarri et al. 1996), the potential for significant interaction is lessened. However this requires a separate study.

Ultimately, the balance of Lotus species which are adopted commercially and the systems they are adapted to will have a strong bearing on which rhizobial strains are progressed to commerce, given the very large symbiotic interactions between host species and rhizobial strain that we have observed. $L$. ornithopodioides is expected to be adopted in medium rainfall wheatbelt zones $(350-500 \mathrm{~mm}$ annual rainfall, Loi et al. 2002) and L. tenuis in defined saline regions
(Teakle et al. 2010) whereas the two resident commercial species L. uliginosus and L. corniculatus appear adapted only to wet regions with permanent pastures, hence the potential conflict between these symbioses might be limited in Australia by their geographic and edaphic separation.

Acknowledgments We would like to thank Mr Neil Schubert and Mrs Regina Carr for their excellent technical assistance, and to Boathaugh Estate for access to the Karridale field site. Financial assistance for this work was provided by the Grains Research and Development Corporation, as well as Murdoch University, Crops and Plants Research Institute (CaPRI) through the Strategic Research Fund.

Open Access This article is distributed under the terms of the Creative Commons Attribution Noncommercial License which permits any noncommercial use, distribution, and reproduction in any medium, provided the original author(s) and source are credited.

\section{References}

Allen ON, Allen EK (1981) The Leguminosae. A source book of characteristics, uses and nodulation. The University of Wisconsin Press, Wisconsin

Ayres JF, Blumenthal MJ, O'Connor JW, Lane LA, Nicol HI (2006) Birdsfoot trefoil (Lotus corniculatus) and greater lotus (Lotus uliginosus) in perennial pastures in eastern Australia. 1. Effects of grazing management on persistence. Aust J Exp Agr 46:503-519

Ballard RA, Slattery JF, Charman N (2004) Host range and saprophytic competence of Sinorhizobium meliloti- A comparison of strains for the inoculation of lucerne, strand and disc medics. Aust J Exp Agr Res 45:209-216

Blumenthal MJ, Kelman WM, Lolicato S, Hare MD, Bowman AM (1993) Agronomy and improvement of Lotus: a review. In: Michalk DL, Craig AD, Collins WJ (eds) Alternative pasture legumes. Department of Primary Industries South Australia, Technical Report 219. pp 74-85

Brockwell J, Hely FW, Neal-Smith CA (1966) Some symbiotic characteristics of rhizobia responsible for spontaneous, effective field nodulation of Lotus hispidus. Aust J Exp Agric Animal Hus 6:365-370

Brockwell J, Gault RR, Zorin M, Roberts MJ (1982) Effects of environmental variables on the competition between inoculum strains and naturalised populations of Rhizobium trifolium for nodulation of Trifolium subterraneum L. and on rhizobia persistence in the soil. Aust J Agr Res 33:803815

Brockwell J, Bottomley P, Thies JE (1995) Manipulation of rhizobia microflora for improving legume productivity and soil fertility: a critical assessment. Plant Soil 174:143-180

Bullard GK, Roughley RJ, Pulsford DJ (2005) The legume inoculant industry and inoculant quality control in Australia: 1953-2003. Aust J Exp Agr 45:127-140 
Chatel DL, Parker CA (1973) Survival of field-grown rhizobia over the dry summer period in Western Australia. Soil Biol Biochem 5:415-423

Cocks PS, Mathison MJ, Crawford EJ (1980) From wild plants to pasture cultivars: annual medics and subterranean clover in southern Australia. In: Summerfield RJ, Bunting $\mathrm{AH}$ (eds) Advances in legume science. Ministry of Agriculture and Fisheries, London, pp 569-596

Craig AD, Sandral GA, Dear BS, Latta RA, Evans PM, Hill NL (2000) Register of Australian herbage plant cultivars. B. Legumes. 1. Clover. Trifolium michelianum Savi (balansa clover) cv. Frontier. Aust J Exp Agr 40:1201-1202

Davies SR, Howieson JG, Yates RJ, Lane PA (2005) Selection and evaluation of root nodule bacteria for Dorycnium spp. Aust J Exp Agr 45:241-246

Garau G, Reeve WG, Brau L, Deiana P, Yates RJ, James D, Tiwari R, O'Hara GW, Howieson JG (2005) The symbiotic requirements of different Medicago spp. suggest the evolution of Sinorhizobium meliloti and S. medicae with hosts differentially adapted to soil $\mathrm{pH}$. Plant Soil 276:263-277

Gault RR, Pilka A, Hebb DM, Brockwell J (1994) Nodulation studies on legumes exotic to Australia: symbiotic relationships between Chamaecytisus palmensis (tagasaste) and Lotus spp. Aust J Exp Agr 34:385-394

Harden GW (1991) Flora of New South Wales, Vol 2 Fabaceae. New South Wales University Press

Harris CA, Blumenthal MJ, Scott JM (1993) Survey of the use and management of Lotus pedunculatus cv. Grasslands Maku in eastern Australia. Aust J Exp Agr 33:41-47

Hill MJ, Donald GE (1998) 'Australian temperate pastures database'. [Computer file]. CSIRO, Perth

Howieson JG (1995) Rhizobial persistence and its role in the development of sustainable agricultural systems in Mediterranean environments. Soil Biol Biochem 27:603-610

Howieson JG, Loi A, Carr SJ (1995) Biserrula pelecinus L. -a legume pasture species with potential for acid, duplex soils which is nodulated by unique root-nodule bacteria. Aust $\mathrm{J}$ Agr Res 46:997-1007

Howieson JG, Ewing MA (1986) Acid tolerance in the Rhizobium meliloti-Medicago symbiosis. Aust J Agr Res 37:55-64

Howieson JG, O'Hara GW, Carr SJ (2000a) Changing roles for legumes in Mediterranean agriculture: developments from an Australian perspective. Field Crop Res 65:107-122

Howieson JG, Evans P, Nutt B (2000b) Estimation of hoststrain compatibility for symbiotic N-fixation between Rhizobium meliloti, several annual species of Medicago and Medicago sativa. Plant Soil 219:49-55

Howieson JG, Yates RJ, O'Hara GW, Ryder M, Real D (2005) The interactions of Rhizobium leguminosarum biovar trifolii in nodulation of annual and perennial Trifolium spp. from diverse centres of origin. Aust J Exp Agr 45:199-207

Howieson JG, Yates RJ, Foster K, Real D, Besier RB (2008) Prospects for the future use of legumes. In: Dilworth MJ, James EK, Sprent JI, Newton WE (eds) Nitrogen-Fixing leguminous symbioses. Springer, Dordrecht, pp 363-387

Hughes SJ, Snowball R, Reed KFM, Cohen B, Gajda K, Williams AR, Groeneweg AR (2008) The systematic collection and characterisation of herbaceous forage species for recharge and discharge environments in southern Australia. Aust J Exp Agr 48:397-408

Hussey BMJ, Keighery GJ, Cousens RD, Dodd J, Lloyd SG (2007) Western weeds: a guide to the weeds of Western Australia, 2nd edn. Scott Print, Perth

Irisarri P, Milnitsky F, Monza J, Bedmar EJ (1996) Characterization of rhizobia nodulating Lotus subbiflorus from Uruguayan soils. Plant Soil 180:39-47

Jessop JP, Toelken HR (1986) Flora of South Australia, I-IV. South Australian Government Printing Division, Adelaide

Kelman WM (1993) Lesser known Lotus species In: Michalk DL, Craig AD, CollinsWJ (eds) Alternative pasture legumes 1993. Department of Primary Industries South Australia, Technical Report 219, pp. 86-87

Loi A, Sandral GA, Gajda K, McRobb R, Snowball R, Lopez FG (2002) Lotus ornithopodioides L. a new pasture legume with potential for Mediterranean farming systems. In McComb JA (ed) Proceedings of the Plant Breeding Conference, Perth, W Aust pp 144-146 (Australasian Plant Breeding Association: Perth, W. Aust.)

Lowther WL, Hay RJM, Ryan DL (1987) Effect of strain of rhizobia, lime, and phosphorus on the dry matter yield of three lotus species in differing environments in Otago and Southland. NZ J Exp Agric 15:135-142

McKnight T (1949) Efficiency of isolates of Rhizobium in the cow pea group, with proposed additions to this group. Q J Agric Sci 6:61-76

Nandasena KG, O'Hara GW, Tiwari RP, Yates RJ, Howieson JG (2001) The phylogenetic relationships of three bacteria strains isolated from the pasture legume Biserrula pelecinus L. Int J Syst Evol Microbiol 51:1983-1986

Nandasena KG, O'Hara GW, Tiwari RP, Howieson JG (2006) Rapid in situ evolution of nodulating strains for Biserrula pelecinus $\mathrm{L}$. through lateral transfer of a sybmiosis island from the original mesorhizobial inoculant. Appl Environ Microbiol 72:7365-7367

Nandasena KG, O'Hara GW, Tiwari RP, Willems A, Howieson JG (2009) Mesorhizobium australicum sp. nov. and Mesorhizobium opportunistum sp. nov. isolated from Biserrula pelecinus L. growing in Australia. Int J Syst Evol Microbiol 59:2140-2147

Patrick HN, Lowther WL (1992) Response of Lotus corniculatus to inoculation and pelleting on a range of Otago tussock grassland environments. Proc NZ Grassland Assoc 54:105-109

Puckridge DW, French RJ (1983) The annual legume pasture in cereal-ley farming system of Southern Australia: a review. Agric Ecosyst Environ 9:229-267

Real D, Warden J, Sandral GA, Colmer TD (2008) Waterlogging tolerance and recovery of ten Lotus species. Aust J Exp Agr 48:480-487

Robson AD (1988) Nutrient requirements of pulses. In: Summerfield RJ (ed) WorldCrops: cool season food legumes. Kluwar Academic Publishers, Dordrecht, pp 869-881

Safronova VI, Piluzza G, Belimov AA, Bullitta S (2004) Phenotypic and genotypic analysis of rhizobia isolated from pasture legumes native of Sardinia and Asinara Island. Antonie Van Leeuwenhoek 85:115-127

Schachtman DP, Kelman WM (1991) Potential of Lotus germplasm for the development of salt, aluminium and 
manganese tolerant pasture plants. Aust J Agr Res 42:139-149

Somasegaran P, Hoben HJ (1985) Methods in legume-Rhizobium technology. University of Hawaii NifTAL Project, Paia

Sullivan JT, Patrick HN, Lowther WL, Scott DB, Ronson CW (1995) Nodulating strains of Rhizobium loti arise through chromosomal symbiotic gene transfer in the environment. Proc Natl Acad Sci USA 92:8985-8989

Teakle NL, Snell A, Real D, Barrett-Lennard EG, Colmer TD (2010) Variation in salinity tolerance, early shoot mass and shoot ion concentrations within Lotus tenuis: towards a perennial pasture legume for saline land. Crop Past Sci 61:379-388

Vincent JM (1970) A manual for the practical study of root nodule bacteria. Blackwell Scientific Publications, Oxford
Wedderburn ME (1986) Effect of applied nitrogen, increased inoculation, broadcast lime, and seed pelleting on establishment of Lotus pedunculatus cv. 'Grasslands Maku' in tussock grasslands. NZ J Exp Agric 14:31-36

Yates RJ, Howieson JG, Real D, Reeve WG, Vivas-Marfisi A, O'Hara GW (2005) Evidence of selection for effective nodulation in the Trifolium spp. symbiosis with Rhizobium leguminosarum biovar trifolii. Aust J Exp Agr 45:189-198

Yates RJ, Howieson JG, Reeve WG, Braü L, Speijers J, Nandasena K, Real D, Sezmis E, O'Hara GW (2008) Host-strain mediated selection for an effective nitrogenfixing symbiosis between Trifolium spp. and Rhizobium leguminosarum biovar trifolii. Soil Biol Biochem 40:822833 